\title{
Belinurus Bronn, 1839 (Chelicerata, Xiphosura) has priority over Bellinurus Pictet, 1846
}

\author{
James C. Lamsdell ${ }^{1} \odot$ and Matthew E. Clapham ${ }^{2}$ \\ ${ }^{1}$ Department of Geology and Geography, West Virginia University, Morgantown, West Virginia 26501, USA <james.lamsdell@mail.wvu.edu> \\ ${ }^{2}$ Department of Earth and Planetary Sciences, UC Santa Cruz, Santa Cruz, California 95064, USA <mclapham@ucsc.edu>
}

In the first half of the nineteenth century, a marked shift occurred in our understanding and treatment of the chelicerate fossil record, with the differentiation and recognition of entirely extinct genera for the first time. At the heart of this taxonomic revolution were the Eurypterida (sea scorpions) and Xiphosura (horseshoe crabs), although both groups were in fact considered crustaceans until Lankester's (1881) seminal comparative anatomical study of the extant xiphosuran Limulus Müller, 1785 and modern scorpions. The oldest available eurypterid genus is Eurypterus deKay, 1825; the oldest available fossil arachnid genus name is that of the scorpion Cyclophthalmus Corda, 1835. However, there has been considerable historical confusion over the oldest available fossil xiphosuran genus name, which has been recognized alternately as Belinurus König (with a publication date of either 1820 or 1851) or the synonymous Bellinurus Pictet, 1846. Most recent treatments (e.g., Selden and Siveter, 1987; Anderson and Selden, 1997; Anderson et al., 1997; Lamsdell, 2016, 2021; Bicknell and Pates, 2020) have favored Bellinurus Pictet, 1846 as the available name; however, Haug and Haug (2020) recently argued that Belinurus König, 1820 is valid and has priority, a position then followed by Lamsdell (2020), prompting a reinvestigation of the taxonomic history of the genus. Upon review, it is clear that neither of the previously recognized authorities for Belinurus are accurate and that the two candidate type species for each genus are, in fact, synonyms. Given the convoluted and at times almost illogical history of the competing names, along with the most recent controversy as to which has priority, we present a complete history of the treatment of the genus to resolve the issue.

The issue arises from the partial publication of König's (1825) Icones Fossilium Sectiles. This volume (Centuria Prima) was bound and published, comprising one hundred figures across eight plates with associated descriptions. Planned further volumes of Icones Fossilium Sectiles beyond the first were never published (Urban, 1851); however, it is apparent that a limited number of lithographs for the plates for the second and third volumes were produced and shared by König among interested parties (Woodward, 1830). Among these plates (figure 230, on plate 18) was a single specimen of a small horseshoe crab labeled simply Belinurus bellulus.

The informal proliferation of these plates created a scenario in which the proposed name was widely known among researchers but explicitly recognized as unpublished (see Woodward, 1830) and presumably therefore unavailable. Buckland (1837), in his contribution to the Bridgewater Treatise series, figured and described a new horseshoe crab species as Limulus trilobitoides, explicitly stating that this new species was the same as König's unpublished Belinurus bellulus and Martin's (1809) Entomolithus Monoculites? Lunatus (a non-binomial name that has been suppressed by the International Commission on Zoological Nomenclature along with all other names within Petrificata Derbiensia). Subsequently, Louis Agassiz, in his German translation of Buckland's (1839) Bridgewater Treatise, followed Buckland's description of Limulus trilobitoides with a note that the genus Bellinurus König [sic] is deserving of recognition as a distinct genus from Limulus (pl. 46; it is worth noting that this is the first recorded occurrence of the alternative Bellinurus spelling and that it follows an accurate transcription of the spelling of Belinurus from Buckland's text on the same page). In the same year, a summary list of fossil horseshoe crabs appeared in the Neues Jahrbuch für Mineralogie, Geognosie, Geologie und Petrefaktenkunde, which was edited by Karl von Leonhard and Heinrich Bronn. The summary itself is not attributed to either editor; however, the article stated that it was done at the request of van der Hoeven. In turn, van der Hoeven (1838) stated that he had been in contact with Bronn regarding the status of the fossil xiphosuran species, and so Bronn (1839) can be reliably ascribed as the author of the article. In it, Bronn directly assigned the species Entomolithus Monoculites? Lunatus Martin, 1809 (as "Entomolites monoculites") and Limulus trilobitoides Buckland to the genus Belinurus König, with no reference to $B$. bellulus König. However, the species reappeared in Morris's (1843) A Catalogue of British Fossils, where it was listed as a synonym of Limulus trilobitoides Buckland.

Later, in his Traité élémentaire de paléontologie, Pictet (1846) included the genus Bellinurus König-once again misspelled-to which he assigned the species Limulus trilobitoides, with the erroneous taxonomic authority of König (notably, there was again no reference to $B$. bellulus König), although the second edition listed $B$. bellulus König as a senior synonym of Limulus trilobitoides (Pictet, 1854). Matters were further complicated by Baily $(1859 \mathrm{a}-\mathrm{c})$, who in a series of papers utilized the name Bellinurus König, recognizing B. bellulus König as a synonym of $B$. trilobitoides (Buckland) and proposing the genus Steropis to accommodate a variety of species, including B. trilobitoides (Buckland). Baily (1863) later recognized Steropis as a junior synonym of Belinurus König, 1820 (potentially the year that the unpublished lithographs were first made available), stating that Pictet (1846) had made the genus name 
available. Baily also here treated $B$. bellulus König, 1820 as a valid and available species for the first time and considered it to have priority over B. trilobitoides (Buckland). Henry Woodward, in his extensive works on British fossil chelicerates, was inconsistent in his treatment of the genus, at first attributing Baily (1863) as the authority for Belinurus König with B. trilobitoides (Buckland) as the type species (Woodward, 1867) before later following Baily (1863) in recognizing Bellinurus König, 1820 with $B$. bellulus König, 1820 as the valid type species (Woodward, 1872, 1907).

Moving into the twentieth century, there appeared to be a consensus that Belinurus König, 1820 was the accurate name and authority, with $B$. trilobitoides (Buckland) being a junior synonym of the type species $B$. bellulus König (Dix and Pringle, 1929; Eller, 1938; Størmer, 1952). Uncertainties regarding the taxonomic history of the species continued, however, with Størmer (1952) erroneously listing Woodward (1866-1878) as the taxonomic authority for B. bellulus. Størmer (1955) later compounded this error in the Treatise on Invertebrate Paleontology, which continued to recognize Belinurus König, 1820, but incorrectly listing Meek and Worthen (1865) as the authority of the junior synonym Bellinurus.

This situation changed dramatically with the publication of Morris's (1980) Catalogue of the type and figured specimens of fossil Crustacea (excl. Ostracoda), Chelicerata, Myriapoda and Pycnogonida in the British Museum (Natural History). In it, Morris reported that the second part of König's work had become available only after his death and that the earliest the genus and species could date to is 1851. This would render Bellinurus, made available by Pictet in 1846, as having priority over Belinurus König, c. 1851. Similarly, B. trilobitoides (Buckland, 1837 ) would have priority over B. bellulus König, c. 1851. The next treatment of the group, by Selden and Siveter (1987), followed Morris in recognizing Bellinurus Pictet as having priority but considered B. bellulus König, c. 1851 the valid type species. Subsequent workers all recognized Bellinurus Pictet, 1846 as the appropriate taxon name and authority (Schultka, 1994; Anderson and Selden, 1997; Anderson et al., 1997; Lamsdell, 2016, 2021; Bicknell and Pates, 2020). Very few of these treatments considered the issue of the appropriate type species, although Bicknell and Pates (2020) listed both B. bellulus (ascribed to Pictet, 1846) and B. trilobitoides (Buckland) as distinct, valid species. Then Haug and Haug (2020) argued on the basis of an available scan of Icones Fossilium Sectiles from the Biodiversity Heritage Library that König's plates were published in 1820 and that Belinurus König had priority over Bellinurus Pictet, which Lamsdell (2020) then followed in a comprehensive revision of xiphosurid taxonomy.

With such a turbulent taxonomic history, the question remains: what is the correct formulation of the genus name, and what is the correct taxonomic authority? To determine this, it must first be ascertained whether the plates for König's second volume were published before 1851, or if not, which publication first made Belinurus available and whether it preor post-dated Pictet's making Bellinurus available in 1846. With regard to the publication of König's plates, all contemporary sources (Woodward, 1830; Urban, 1851) are clear in stating that the later volumes of Icones Fossilium Sectiles were not published and the plates were not publicly available. The fact that the plates for the second and third volumes were distributed and appended to bindings of the first volume after König's death, as stated by Sherborn (1902) and Lang et al. (1940), explains the undated binding from the Natural History Museum, London, that led Haug and Haug (2020) to believe that these plates were published before 1851 . The matter then becomes when Belinurus and Bellinurus each first became available. Although Buckland (1837) stated his Limulus trilobitoides is the same as König's Belinurus bellulus, he did so with reference to the unpublished plates and so did not make the genus or species available as per Article 12.3 of the International Code of Zoological Nomenclature (International Commission on Zoological Nomenclature, 1999). Similarly, Agassiz's note in his translation of Buckland (1839) was the first reference to Bellinurus in the literature but did not include an assignation of an available species name and so did not make that spelling of the genus available. However, Bronn's (1839) summary of fossil horseshoe crabs explicitly listed Belinurus König as a valid genus including the valid species Limulus trilobitoides Buckland by indication. This satisfies Article 12.2.5 of the International Code of Zoological Nomenclature (International Commission on Zoological Nomenclature, 1999) and is sufficient for the genus name to become available, whereby its taxonomic authority is Bronn (1839) following Article 50.1 (International Commission on Zoological Nomenclature, 1999). Bellinurus was first made available by Pictet, and so Belinurus Bronn, 1839 is the valid senior synonym of Bellinurus Pictet, 1846. Pictet, however, made no reference to B. bellulus, which Morris (1980) stated was first made available by the distribution of König's plates in or after 1851. If the plates were distributed after 1854, B. bellulus would be attributable to Pictet (1854), who figured a specimen alongside a diagnosis of the species. Irrespective as to whether the species was made available in 1851 or 1854, as B. trilobitoides (Buckland, 1839) and B. bellulus König, c. 1851/Pictet, 1854 are subjective synonyms, $B$. trilobitoides has seniority and is the valid name.

To clarify these issues for future paleontologists, we present a revised systematic paleontology for Belinurus Bronn, 1839, including all currently valid species assignable to the genus.

\section{Systematic paleontology}

Xiphosurida Latreille, 1802

Belinurina von Zittel in von Zittel and Eastman, 1913

Family Belinuridae von Zittel in von Zittel and Eastman, 1913 (= Euproopidae Eller, 1938; = Liomesaspidae Raymond, 1944) Genus Belinurus Bronn, 1839

(= Bellinurus Pictet, 1846; = Steropis Baily, 1859a)

Type species.-Belinurus trilobitoides (Buckland, 1837) (lectotype: BNMH 34889; paralectotype: BMNH 46393) (= Belinurus bellulus König, c. 1851/Pictet, 1854) from the clay-ironstone of the Coalbrookdale Coal Measures, Telford, Shropshire, by subsequent designation.

Other species. - Belinurus carwayensis Dix and Pringle, 1929; Belinurus concinnus Dix and Pringle, 1929; Belinurus grandaevus Jones and Woodward, 1899; Belinurus kiltorkensis Baily, 1869; Belinurus morgani Dix and Pringle, 
1930; Belinurus pustulosus Dix and Pringle, 1929; Belinurus silesiacus (Roemer, 1883); Belinurus sustai (Prantl and Přibyl, 1956); Belinurus trechmanni Woodward, 1918.

Diagnosis.-Belinurid with axis of first thoracetron tergite medially inflated; thoracetron ovoid to semicircular in outline; thoracetron fixed tergopleural spines elongate, needle-like (after Lamsdell, 2020).

\section{Occurrence.-Carboniferous: Canada, Czech Republic,} Germany, and United Kingdom.

Remarks.-Morris (1980) listed two syntypes for Belinurus trilobitoides, one figured by Buckland (1837) and the other not. No lectotype has been subsequently designated, and so here we select Buckland's figured specimen, BMNH 34889, as the lectotype for the species following Article 74.1 of the International Code of Zoological Nomenclature (International Commission on Zoological Nomenclature, 1999). According to Morris, this is also the specimen figured by König (c. 1851). There is no indication as to the identity of the specimen figured by Pictet (1854).

\section{Acknowledgments}

JCL thanks A. Baumgartner and D. Lamsdell for reading through an early draft of the manuscript and helping ensure the convoluted taxonomic history was presented in an understandable format. We thank R. Plotnick and C. Haug for their reviews of the manuscript.

\section{References}

Anderson, L.I., and Selden, P.A., 1997, Opisthosomal fusion and phylogeny of Palaeozoic Xiphosura: Lethaia, v. 30, p. 19-31.

Anderson, L.I., Dunlop, J.A., Horrocks, C.A., Winkelmann, H.M., and Eager, R.M.C., 1997, Exceptionally preserved fossils from Bickershaw, Lancashire UK (upper Carboniferous, Westphalian A (Langsettian)): Geological Journal, v. 32, p. 197-210.

Baily, W.H., 1859a, On a crustacean from the coal-measures, with some remarks on the genus Limulus: Journal of the Geological Society of Dublin, v. 8, p. 89-91.

Baily, W.H., 1859b, Palaeontological notes, in Jukes, J.B., Kinahan, G.H., and Baily, W.H., Explanation of Sheet 137 of the Maps of the Geological Survey of Ireland: Dublin, Alexander Thom \& Sons, p. 12-15.

Baily, W.H., 1859c, On two new species of Crustacea (Bellinurus König) from the Coal Measures in Queen's Country, Ireland; and some remarks on forms allied to them, in British Association for the Advancement of Science, ed., Report of the Twenty-Eighth Meeting of the British Association for the Advancement of Science: London, John Murray, p. 76-78.

Baily, W.H., 1863, Remarks on some Coal Measures Crustacea belonging to the genus Belinurus, König, with description of two new species from Queen's County, Ireland: Annals and Magazine of Natural History, v. 11, p. 107-114.

Baily, W.H., 1869, On fossils obtained at Kiltorcan Quarry, Co. Kilkenny: British Association Report, v. 39, p. 73-75.

Bicknell, R.D.C., and Pates, S., 2020, Pictorial atlas of fossil and extant horseshoe crabs, with focus on Xiphosurida: Frontiers in Earth Science, v. 8, art. 98.

Bronn, H.G., 1839, Fossile Limulus-Arten: Neues Jahrbuch für Mineralogie, Geognosie, Geologie und Petrefaktenkunde, v. 1839, p. 489-490.

Buckland, W., 1837, The Bridgewater treatises on the power, wisdom and goodness of God as manifested in the creation. Treatise IV. Geology and mineralogy with reference to natural theology (second edition): London, William Pickering, $316 \mathrm{p}$.

Buckland, W., 1839, Geologie und Mineralogie in Beziehung zur natürlichen Theologie. Aus dem Englischen, nach der zweiten Ausgabe des Originals [1837], übersetzt und mit Anmerkungen und Zusätzen versehen von L. Agassiz: Neufchatel, Eduard Leibrock, 1135 p.
Corda, A.J.C., 1835, Ueber den in der Steinkohlenformation bei Cholme gefundenen fossilen Scorpion: Verhandlungen der Gesellschaft des vaterländischen Museums in Böhmen, Prag, v. 36, p. 35-43.

DeKay, J.E., 1825, Observations on a fossil crustaceous animal of the order Branchiopoda: Annals of the New York Lyceum of Natural History, v. 1, p. $375-377$.

Dix, E., and Pringle, J., 1929, On the fossil Xiphosura from the South Wales Coalfield with a note on the myriapod Euphoberia: Summary of Progress, Geological Survey of Great Britain, v. 1928, p. 90-113.

Dix, E., and Pringle, J., 1930, Some coal measure arthropods from the South Wales Coalfield: Annals and Magazine of Natural History, v. 6, p. 136-144.

Eller, E.R., 1938, A review of the xiphosuran genus Belinurus with the description of a new species, B. allegayensis: Annals of the Carnegie Museum, v. 27 , p. $129-150$.

Haug, C., and Haug, J.T., 2020, Untangling the Gordian knot—further resolving the superspecies complex of 300-million-year-old xiphosurids by reconstructing their ontogeny: Development Genes and Evolution, v. 230, p. 13-26.

International Commission on Zoological Nomenclature, 1999, International Code of Zoological Nomenclature (fourth edition): London, International Trust for Zoological Nomenclature, $306 \mathrm{p}$.

Jones, T.R., and Woodward, H., 1899, Contributions to fossil Crustacea: Geological Magazine, v. 6, p. 388-395.

König, C., 1825, Icones fossilium sectiles: London, G.B. Sowerby, 4 p.

König, C., c. 1851, Icones fossilium sectiles pls. 9-19: ?London.

Lamsdell, J.C., 2016, Horseshoe crab phylogeny and independent colonisations of freshwater: ecological invasion as a driver for morphological innovation: Palaeontology, v. 59, p. 181-194.

Lamsdell, J.C., 2020, The phylogeny and systematics of Xiphosura: PeerJ, v. 8, e10431.

Lamsdell, J.C., 2021, A new method for quantifying heterochrony in evolutionary lineages: Paleobiology, v. 47 , p. 363-384.

Lang, W.D., Smith, S., and Thomas, H.D., 1940, Index of Palaeozoic Coral Genera: London, British Museum of Natural History, $231 \mathrm{p}$.

Lankester, E.R., 1881, Limulus an arachnid: Quarterly Journal of Microscopical Science, v. 21, p. 504-548.

Latreille, P.A., 1802, Histoire naturelle, générale et particulière, des Crustacés et des Insectes, Volume 3: Paris, F. Dufart, 594 p.

Martin, W., 1809, Petrificata Derbiensia; or Figures and Descriptions of Petrifactions Collected in Derbyshire: Wigan, D. Lyon, $251 \mathrm{p}$.

Meek, F.B., and Worthen, A.H., 1865, Notice of some new types of organic remains from the Coal Measures of Illinois: Proceedings of the Academy of Natural Sciences of Philadelphia, v. 17, p. 41-45.

Morris, J., 1843, A Catalogue of British fossils: London, British Museum (Natural History), $222 \mathrm{p}$.

Morris, S.F., 1980, Catalogue of the type and figured specimens of fossil Crustacea (excl. Ostracoda), Chelicerata, Myriapoda and Pycnogonida in the British Museum (Natural History): London: British Museum (Natural History), $53 \mathrm{p}$.

Müller, O., 1785, Entemostraca, and seu, Insecta testacea quae in aquis Daniae et Norvegie reperit, descripsit et iconibus illustravit: Hauniae, Thiele, $135 \mathrm{p}$.

Pictet, F.J., 1846, Traité élémentaire de paléontologie, Volume 4: Paris, Langlois et Leclerq, $371 \mathrm{p}$.

Pictet, F.J., 1854, Traité élémentaire de paléontologie, Volume 2 (second edition): Paris, Bailliere, $727 \mathrm{p}$.

Prantl, F., and Prribyl, A., 1956, Ostrorepi (Xiphosura) ceskoslovenskeho karbonu: Sborn Ústredn Ústavu Geologického, v. 22, p. 379-424.

Raymond, P.E., 1944, Late Paleozoic xiphosurans: Bulletin of the Museum of Comparative Zoology, v. 64, p. 475-508.

Roemer, F., 1883, Über eine Art der Limuliden-Gattung Belinurus aus dem Steinkohlengebirge Oberschlesiens: Zeitschrift der Deutschen Geologischen Gesellschaft, v. 35, p. 429-432.

Schultka, S., 1994, Bellinurus cf. truemanii (Merostomata) aus dem tiefen Oberkarbon (Namur B/C) von Fröndenberg (Nordrhein-Westfalen, Germany): Paläontologische Zeitschrift, v. 68, p. 339-349.

Selden, P.A., and Siveter, D.J., 1987, The origin of the limuloids: Lethaia, v. 20, p. 383-392.

Sherborn, C.D., 1902, Index animalium sive Index nominum quae ab A.D. MDCCLVIII generibus et speciebus animalium imposita sunt societatibus eruditorum adiuvantibus: Cantabrigiae, Typographio Academico, $1195 \mathrm{p}$.

Størmer, L., 1952, Phylogeny and taxonomy of fossil horseshoe crabs: Journal of Paleontology, v. 26, p. 630-640.

Størmer, L., 1955, Merostomata, in Moore, R., ed. Treatise on Invertebrate Paleontology, Part P, Arthropoda 2, Chelicerata with section on Pycnogonida and Palaeoisopus: Boulder, Colorado and Lawrence, Kansas, Geological Society of America and University of Kansas Press, p. 4-41.

Urban, S., 1851, Obituary-Charles König, Esq.: The Gentleman's Magazine, v. 36, p. $435-436$.

van Der Hoeven, J., 1838, Recherches Sur L'histoire Naturelle Et L'anatomie Des Limules: Leyden, Luchtmans, 48 p. 
von Zittel, K.A., and Eastman, C.R., 1913, Textbook of Palaeontology (second edition): London, Macmillan, $839 \mathrm{p}$.

Woodward, H., 1866-1878, A monograph of the British fossil Crustacea belonging to the order Merostomata: Monograph of the Palaeontographical Society, London, v. 19, 22, 26, 32, 263 p

Woodward, H., 1867, On some points in the structure of the Xiphosura, having reference to their relationship with the Eurypteridae: Quarterly Journal of the Geological Society of London, v. 23, p. 28-37.

Woodward, H., 1872, Notes on some British Palaeozoic Crustacea belonging to the order Merostomata: Geological Magazine, v. 9, p. 433-441.
Woodward, H., 1907, Further notes on the Arthropoda of the British Coal Measures: Geological Magazine, v. 4, p. 539-549.

Woodward, H., 1918, Fossil arthropods from the Carboniferous rocks of Cape Breton, Nova Scotia; and from the Upper Coal Measures, Sunderland, England: Geological Magazine, v. 5, p. 462-471.

Woodward, S., 1830, A Synoptical Table of British Organic Remains: London, Longman, $50 \mathrm{p}$.

Accepted: 21 June 2021 